\title{
Optimization of Production Parameters in Oriented Strand Board (OSB) Manufacturing by Using Taguchi Method
}

\section{Optimizacija parametara u proizvodnji OSB ploča primjenom Taguchijeve metode}

Original scientific paper $\bullet$ Izvorni znanstveni rad Received-prispjelo: 18. 8. 2020. Accepted-prihvaćeno: 26. 5. 2021. UDK: $630 * 863.21$ https://doi.org/10.5552/drvind.2021.2033

(C) 2021 by the author(s). Licensee Faculty of Forestry and Wood Technology, University of Zagreb. This article is an open access article distributed under the terms and conditions of the Creative Commons Attribution (CC BY) license.

\begin{abstract}
Optimization of process conditions in oriented strand board (OSB) manufacturing is a very important issue for both reducing cost and improving the quality of panels. Taguchi experimental design technique was applied to determination and optimization of the most influential controlling parameters of OSB panels such as press condition (pressure-time-temperature) and the ratio of adhesive parameters on modulus of elasticity (MOE). The value of the MOE is one of the very important mechanical properties of OSB panels. For this purpose, several experiments were conducted according to Taguchi L27 orthogonal design. The signal-to-noise (S/N) and the analysis of variance (ANOVA) were used to find the optimum levels and to indicate the impact of the controlling parameters on MOE. A verification test was also performed to prove the effectiveness of Taguchi technique. Since the predicted and the measured values were very close to each other, it was concluded that the Taguchi method was very successful in the optimization of effective parameters in OSB's manufacturing.
\end{abstract}

Keywords: oriented strand board; production parameters; optimization; Taguchi method

SAŽETAK • Optimizacija parametara u proizvodnji ploča s orijentiranim iverjem (OSB ploča) vrlo je važna kako za smanjenje troškova proizvodnje, tako i za poboljšanje kvalitete ploča. Za određivanje najutjecajnijih kontrolnih parametara tijekom proizvodnje OSB ploča i za njihovu optimizaciju primijenjena je Taguchijeva metoda projektiranja eksperimenta. Ispitan je utjecaj uvjeta prešanja (tlaka, vremena i temperature) i omjera parametara lijepljenja na modul elastičnosti (MOE) ploča. Vrijednost modula elastičnosti vrlo je važno mehaničko svojstvo OSB ploča. Stoga je provedeno nekoliko pokusa prema ortogonalnom dizajnu Taguchi L27. Za pronalaženje optimalnih veličina i određivanje utjecaja kontrolnih parametra na modul elastičnosti primijenjeni su omjer signala $i$ šuma $(S / N)$ i analiza varijance (ANOVA). Također je provedena verifikacija kako bi se dokazala učinkovitost Taguchijeve metode. Budući da su predviđene i izmjerene vrijednosti bile vrlo blizu jedne drugima, zaključeno je da je Taguchijeva metoda bila vrlo uspješna u optimizaciji utjecajnih parametara u proizvodnji OSB ploča.

Ključne riječi: OSB ploča; proizvodni parametri; optimizacija; Taguchijeva metoda

\footnotetext{
Author is assistant professor at Ondokuz Mayıs University, Faculty of Engineering, Department of Industrial Engineering, Samsun, Turkey.

${ }^{2}$ Author is associate professor at Ondokuz Mayıs University, Faculty of Engineering, Department of Industrial Engineering, Samsun, Turkey.
} 


\section{INTRODUCTION}

\section{UVOD}

Oriented strand boards (OSB) are a relatively new kind of wood-based panels that are defined in the European Standard. Particle boards are classified depending on the size and orientation of their components (Rebollar et al., 2007). OSB is a multilayer structural panel made from wood strands by drying, sizing, oriented formation and hot pressing, in which the strands comprise uniformly thick and long wood shavings (Sumardi et al., 2007). OSBs are made of a threelayer mat called strand with highly densified core. While the strands in the surface layers are aligned in parallel to the board length or width, the strands in the core layers can be randomly oriented or perpendicular to the surface layers for enhancing product strength and stiffness (Semple et al., 2015). OSBs, wood-based panel products are classified into four types ranging from general purpose boards to high load-bearing boards in the humid conditions according to the European Standard (EN 300: 2006). Oriented strand board has been produced as a structural panel material, replacing softwood plywood in North America since the early 1980s (Spelter et al.,1997). OSB market is also growing worldwide, and it is expected a growth rate of nearly $28 \%$ until 2022 (Ferro et al., 2018).

OSB has been mostly used in building, construction, transportation, furniture and packaging industries. In the field of civil engineering, as a structural or nonstructural panel, OSB is gradually accepted on the construction market. Furthermore, OSB is commonly used as shear wall material of buildings and in the construction of furniture skeleton (Jin et al., 2016). The application of OSB panels is very significant in construction and furniture industry. With the general decrease of forest resources in the world, the use of OSB in many areas, especially in furniture manufacturing and civil construction, as well as wall coverings and roof panels, becomes essential (Kasal, 2008; Benetto et al., 2009).

Mechanical and physical properties of OSB panels can be affected by many factors such as raw materials, pressing parameters (pressure-temperature and time), type of adhesive, adhesive ratio, and density profile of the panel (Ciobanu et al., 2014). Physical and mechanical properties of OSB are in agreement with the changes in chemical components caused by the treatments (Fatrawana et al., 2019). As a result of drying and hot-pressing processes in the manufacturing of OSBs, volatile organic compounds (VOC) are emitted into the atmosphere.

The majority of wood-based panels rely on thermosetting polymers. Urea formaldehyde adhesive can be especially chosen due to its suitable combination, including low cost, fast reaction time in hot press, low cure temperatures, and excellent thermal properties (Aydin et al., 2006). The OSB manufacturer uses water resistant adhesive such as isocyanates (polymeric diphenyl methane diisocyanate (PMDI)), phenol-formaldehyde (PF), melamine-urea-phenol formaldehyde (MUPF) or UF-melamine resins. OSB is produced to meet specific requirements related to size and thickness of strand, density, and texture. These products are widely used for indoor and outdoor structural applications (Dumitrascu et al., 2020).

There are a lot of factors like the type of raw material, size of the particle, adhesive ratio and press conditions (time-pressure-temperature) that affect the properties of OSBs. It is stated that a good performance of the OSB product can be achieved by using optimum process parameters (Barnes, 2000). Experimentation is a frequent task to measure and analyze the output, and for this purpose, engineers/researchers use many tools like statistics, analytical models, etc., regardless of their background (Bisgaard, 1991). In today's era, the purpose of experiments in industries is essentially optimization and robust design analysis (Davis and John, 2018). Design of Experiments (DoE) is one of the most important tools used in determining optimum conditions. DoE techniques enable designers to determine simultaneously the individual and interactive effects of many factors that could affect the output in any design. DoE also provides a full insight of interaction between design elements. Smardzewski (2019) examined experimental and numerical analysis of wooden sandwich panels with an auxetic core and oval cells. Velosa et al. (2013) applied Taguchi method to design the experiment and investigate the influence of various parameters of compression molding process on the mechanical properties of composite panels. Auchet et al. (2018) designed and conducted the drilling experiments according to Taguchi's method to predict the influence of cutting parameters on thrust force in drilling of particleboard panels. Response surface methodology has been adopted by Davim et al. (2008) to investigate the relationships and parametric interaction between two controllable variables, namely, feed rate and cutting speed on the delamination factor at entry and exit of the holes in drilling of MDF.

The factors that affect the mechanical properties of OSB panels can be expressed as adhesive type and amount, type of raw material, moisture content, chip or strand size, and press conditions (time-pressure-temperature, etc.). On the other hand, the $M O E$ value is a mechanical property that should be considered in applications such as the building construction sector and interior decoration. Therefore, it is necessary to create optimal production conditions and determine the effect of the factors affecting the amount of $M O E$. This study aims to determine and optimize the most influential controlling parameters of OSB panels such as press condition (pressure-time-temperature) and the ratio of adhesive parameters on the modulus of elasticity $(M O E)$. For this purpose, the Taguchi experimental design technique is applied and the results are analyzed in detail.

\section{MATERIALS AND METHODS} 2. MATERIJALI I METODE

\subsection{Manufacturing of OSB panels}

2.1. Proizvodnja OSB ploča

Scots pine (Pinus sylvestris L.) was used in the production of the oriented strand boards (OSB). The 
strands dimension was approximately $80 \mathrm{~mm}$ long, 20 $\mathrm{mm}$ wide, and $0.7 \mathrm{~mm}$ thick. First, the wood strands were dried to 2 or $3 \%$ moisture content before adhesive was sprayed on them. Then, phenol formaldehyde adhesive was applied in 6,9 and 12 percent ratios based on the weight of oven dry wood strands. The OSB panels were produced under the fallowing conditions: press time (3, 6 and 9 minutes), temperature of press plates was $\left(175,185\right.$ and $\left.195^{\circ} \mathrm{C}\right)$ and press pressure $\left(30,40\right.$ and $\left.50 \mathrm{~kg} / \mathrm{cm}^{2}\right)$. The shelling ratio was 40 $\%$ for core layer and $60 \%$ for face layer, and density of the boards was aimed at $0.65 \mathrm{~g} / \mathrm{cm}^{3}$. Mats having dimensions of $56 \mathrm{~cm} \times 56 \mathrm{~cm} \times 1.2 \mathrm{~cm}$ were formed. OSB panels were totally produced in this study and labeled from 1 to 27 . All mats were pressed under automatically controlled conditions. After pressing, the boards were conditioned to constant weight at $(65 \pm 5)$ $\%$ relative humidity and at a temperature of $(20 \pm 2){ }^{\circ} \mathrm{C}$ until they reached stable weight.

\subsection{Determination of modulus of elasticity}

2.2. Određivanje modula elastičnosti

The modulus of elasticity in bending strength is measured according to EN 310: 1996 standard. The values of modulus of elasticity of test panels produced in this study were determined by using Zwick/Roell Z050 universal test device with the capacity of 5000 $\mathrm{kg}$. This machine is able to record the loading wedge movement (with a precision of $0.01 \mathrm{~mm}$ ) and load (with a precision of $0.01 \mathrm{~N}$ ) every $1 \mathrm{~s}$. In testing, the loading mechanism was operated with a velocity of 5 $\mathrm{mm} / \mathrm{min}$. The calculation of $M O E$ was based on the forces measured at $15 \%$ and $45 \%$ of the maximum loading force (force of destruction), and the corresponding deflections of the bent beam were measured by extensometer. The $M O E$ was calculated using Eq 1:

$$
M O E=\frac{l^{3} \cdot\left(F_{2}-F_{1}\right)}{4 \cdot b \cdot h^{3} \cdot\left(u_{1}-u_{2}\right)}
$$

where $l$ is the span of supports $(360 \mathrm{~mm}), F_{2}$ and $F_{1}$ are forces at $5 \%$ and $15 \%$ level of the maximum force $F_{\text {max }}, b$ is the width of the cross-section of sample and $h$ is the thickness of sample (height of cross-section), $u_{45 \%}$ and $u_{15 \%}$ are deflections at forces $F_{45 \%}$ and $F_{15 \%}$. The values of $M O E$ calculated from the five measured specimens from each board were averaged.

\subsection{Taguchi method}

\subsection{Taguchijeva metoda}

The technique of defining and investigating some conditions in an experiment involving multiple factors is known as the experimental design. In the literature, this technique is also referred to as factorial design. Experimental design methods were developed originally by Fisher (1992). However, the classical experimental design method is complex, time-consuming and is not efficient under today's industrial competitive conditions. Furthermore, a large number of experiments have to be carried out when the number of the process parameters increases. To reduce the number of experiments, Taguchi used a special design of orthogonal arrays to study the entire parameter space (matrix of ex- periments) with a smaller number of experiments. With the help of this matrix, the maximum information from a minimum number of trials and the best level of each parameter can be obtained for an objective function. The steps to be followed to design the experiment according to the Taguchi method are as follows:

1. Identify the signal and noise factor. Signal factors are the input parameters of the problem that change during the experiment to obtain the optimal conditions. Noise factors are also called the all factors that cause changes but are assumed constant during the tests.

2. Determine the number of levels for the parameters and possible interactions between the parameters.

3. Select the appropriate orthogonal array and assign the parameters to the orthogonal array.

4. Conduct the experiments based on the arrangement of the orthogonal array.

5. Calculate the response of the experimental trails using the signal-to noise $(S / N)$ ratio and performing a statistical analysis of variance (ANOVA) to see which parameters are statistically significant. There are three categories of quality characteristic in the analysis of the $S / N$ ratio. Lower is better, nominal is better, higher is better, and these can be expressed by the following equations (Agrawal et al., 2018).

a. The lower is better characteristics are expressed by the following equation:

$$
S / N=-10 \log _{10}\left(\frac{1}{n} \sum h^{2}\right)
$$

b. The nominal is better characteristics are expressed by the following equations:

$$
\begin{aligned}
& S / N=-10 \log _{10}\left(s^{2}\right) \\
& S / N=10 \log _{10}\left(\frac{y^{2}}{s^{2}}\right)
\end{aligned}
$$

c. The larger is better characteristics are expressed by the following equation:

$$
S / N=-10 \log _{10}\left(\frac{1}{n} \sum \frac{1}{h^{2}}\right)
$$

In the above equations, $n$ - number of cases / test runs; - experimental results/data; where $Y$ - mean of responses for a combination of selected factor level; $s$ $=$ standard deviation of the responses for given factorlevel combination.

6. Select the optimal levels of parameters.

7. Verify the optimal parameters through the confirmation experiment.

\section{RESULTS AND DISCUSSION 3. REZULTATI I RASPRAVA}

The density and moisture content values of OSBs were determined according to the applicable standards (TS EN 323, 1999; TS EN 322, 1999). It was observed that the obtained density and moisture content values of the test samples changed between $0.60-0.72 \mathrm{~g} / \mathrm{cm}^{3}$ and $5-7 \%$, respectively. In the study, it was seen that the values obtained from experimental studies were in harmony with the targeted moisture content and den- 
Table 1 Selected experimental parameters and their assigned levels

Tablica 1. Odabrani eksperimentalni parametri i njihove dodijeljene razine

\begin{tabular}{|c|l|c|c|c|}
\hline $\begin{array}{c}\text { Symbol } \\
\text { Simbol }\end{array}$ & \multicolumn{1}{|c|}{$\begin{array}{c}\text { Parameters } \\
\text { Parametri }\end{array}$} & \multicolumn{3}{|c|}{$\begin{array}{c}\text { Levels of parameters } \\
\text { Razina parametara }\end{array}$} \\
\hline & & $\mathbf{1}$ & $\mathbf{2}$ & $\mathbf{3}$ \\
\hline $\mathrm{A}$ & Pressure / tlak, $\mathrm{kg} / \mathrm{cm}^{2}$ & 30 & 40 & 50 \\
\hline $\mathrm{B}$ & Time / vrijeme, $\mathrm{min}$ & 3 & 6 & 9 \\
\hline $\mathrm{C}$ & $\begin{array}{l}\text { Temperature } \\
\text { temperatura, }^{\circ} \mathrm{C}\end{array}$ & 175 & 185 & 195 \\
\hline $\mathrm{D}$ & $\begin{array}{l}\text { Adhesion rate } \\
\text { stupanj adhezije, \% }\end{array}$ & 6 & 9 & 12 \\
\hline
\end{tabular}

sity values. In this study, the parameters of press pressure, press time, press temperature and adhesion ratio were considered as controllable (signal) factors that have three levels each (Table 1). Other parameters were considered as non-controllable (noise) factors and were considered constant during the tests. The effects of four signal factors, each at three levels, on the value of MOE were studied.

Considering the input parameters and their levels, L27 orthogonal arrays were selected as the experimental matrix. To analyze the experimental result, the interactions among the main factors were not considered and the $S / N$ ratio was computed for each experiment.

Table 2 presents the experimental plan and results as an L27 orthogonal array and the corresponding $S / N$ ratio. The largest value of $M O E$ is very important for quality improvement of the product. For this reason, the "larger-the-better" concept has been applied for the calculation of $S / N$ ratios. The influence of control parameters such as press pressure, press time, temperature of the press plate, and the adhesive ratio on the $M O E$ was analyzed using $S / N$ response table (Table 3 ). In Table 3, the delta value is equal to the difference between maximum and minimum $S / N$ ratios values for
Table 2 Orthogonal array of L27 for modulus of elasticity

Tablica 2. Ortogonalni niz L27 za modul elastičnosti

\begin{tabular}{|c|c|c|c|c|c|c|}
\hline $\begin{array}{c}\text { Exp. No } \\
\text { Broj eksperimenta }\end{array}$ & & $\begin{array}{l}\text { in } \mathbf{p} \\
v n i\end{array}$ & ram & & $\begin{array}{l}\text { MOE } \\
\mathrm{N} / \mathrm{mm}^{2}\end{array}$ & $S / N$ \\
\hline & A & B & $\mathrm{C}$ & $\mathrm{D}$ & & \\
\hline 1 & 30 & 3 & 175 & 6 & 5946 & 75.48 \\
\hline 2 & 30 & 3 & 175 & 9 & 3034 & 69.64 \\
\hline 3 & 30 & 3 & 175 & 12 & 2396 & 67.59 \\
\hline 4 & 30 & 6 & 185 & 6 & 6817 & 76.67 \\
\hline 5 & 30 & 6 & 185 & 9 & 8067 & 78.13 \\
\hline 6 & 30 & 6 & 185 & 12 & 3655 & 71.26 \\
\hline 7 & 30 & 9 & 195 & 6 & 5204 & 74.33 \\
\hline 8 & 30 & 9 & 195 & 9 & 7537 & 77.54 \\
\hline 9 & 30 & 9 & 195 & 12 & 5404 & 74.65 \\
\hline 10 & 40 & 6 & 195 & 6 & 6796 & 76.65 \\
\hline 11 & 40 & 6 & 195 & 9 & 7876 & 77.93 \\
\hline 12 & 40 & 6 & 195 & 12 & 6722 & 76.55 \\
\hline 13 & 40 & 9 & 175 & 6 & 6769 & 76.61 \\
\hline 14 & 40 & 9 & 175 & 9 & 7490 & 77.49 \\
\hline 15 & 40 & 9 & 175 & 12 & 6131 & 75.75 \\
\hline 16 & 40 & 3 & 185 & 6 & 6542 & 76.31 \\
\hline 17 & 40 & 3 & 185 & 9 & 5839 & 75.33 \\
\hline 18 & 40 & 3 & 185 & 12 & 2472 & 67.86 \\
\hline 19 & 50 & 9 & 185 & 6 & 5641 & 75.03 \\
\hline 20 & 50 & 9 & 185 & 9 & 6227 & 75.89 \\
\hline 21 & 50 & 9 & 185 & 12 & 5238 & 74.38 \\
\hline 22 & 50 & 3 & 195 & 6 & 4779 & 73.59 \\
\hline 23 & 50 & 3 & 195 & 9 & 2998 & 69.54 \\
\hline 24 & 50 & 3 & 195 & 12 & 2308 & 67.26 \\
\hline 25 & 50 & 6 & 175 & 6 & 6223 & 75.88 \\
\hline 26 & 50 & 6 & 175 & 9 & 8222 & 78.30 \\
\hline 27 & 50 & 6 & 175 & 12 & 5406 & 74.66 \\
\hline
\end{tabular}

levels of each parameter, and the influence order of parameter was determined by comparison of delta values.

The level values of control factors for $M O E$ given in Table 3 are shown in graph forms in Figure 1. The optimum set of parameters for obtaining maximum $M O E$ can be determined by selecting the largest value

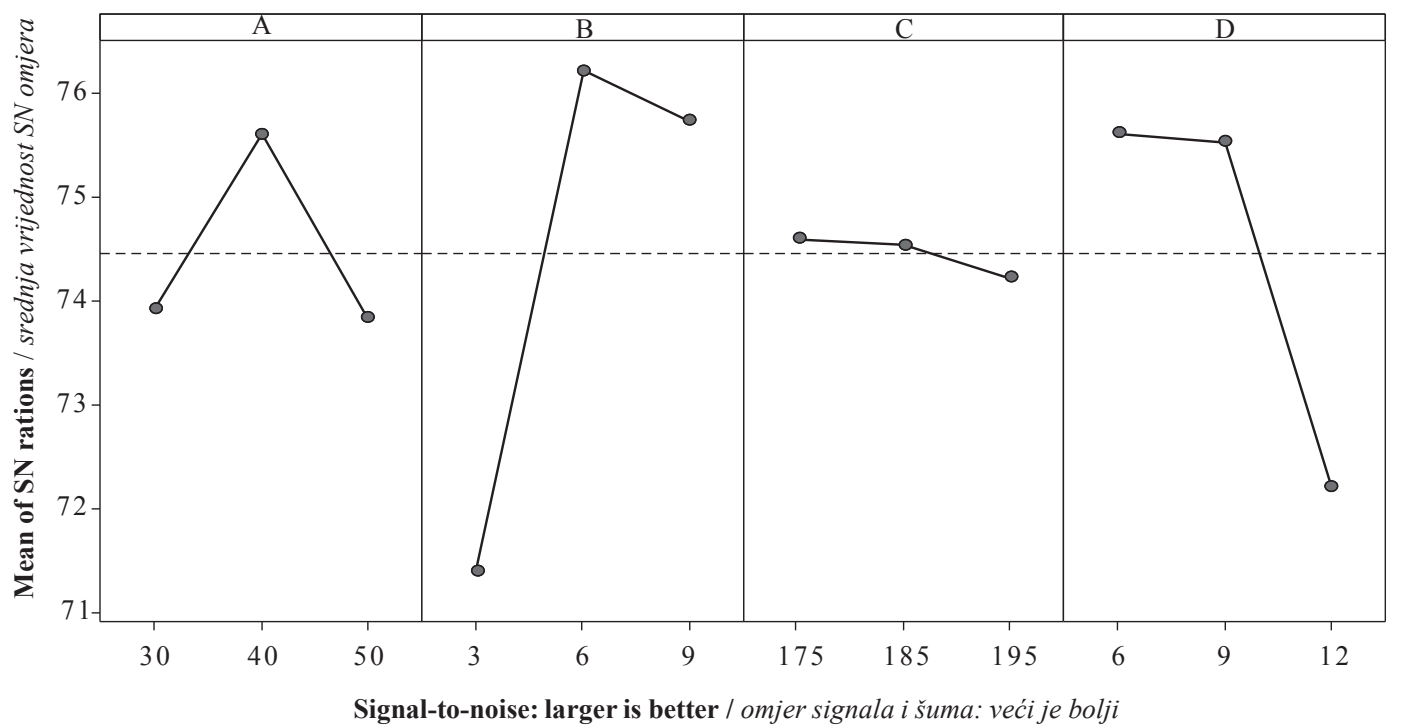

Figure 1 Effects of control parameters on $M O E$ (SNR data)

Slika 1. Utjecaj kontrolnih parametara na modul elastičnosti (SNR podatci) 
Table 3 Response table for signal to noise ratios

Tablica 3. Tablica odgovora za omjere signala i šuma

\begin{tabular}{|c|c|c|c|c|}
\hline Level & A & B & C & D \\
\hline 1 & 73.92 & 71.40 & 74.60 & 75.62 \\
\hline 2 & $\mathbf{7 5 . 6 1}$ & $\mathbf{7 6 . 2 2}$ & $\mathbf{7 4 . 5 4}$ & $\mathbf{7 5 . 5 3}$ \\
\hline 3 & 73.84 & 75.74 & 74.23 & 72.22 \\
\hline Delta & 1.77 & 4.82 & 0.37 & 3.40 \\
\hline Rank & 3 & 1 & 4 & 2 \\
\hline
\end{tabular}

of $S / N$ ratio for each factor. Hence, the optimum control parameter level is A2 (factor A at level 2, $S / N=$ 75.61), B2 (factor B at level 2, $\mathrm{S} / \mathrm{N}=76.22$ ), $\mathrm{C} 1$ (factor $\mathrm{C}$ at level 1, $S / N=74.60$ ), and D1 (factor D at level 1, $S / N=75.62)$. In other words, an optimum $M O E$ value was obtained at a press pressure of $40 \mathrm{~kg} / \mathrm{cm}^{2}$, press time of $6 \mathrm{~min}$, temperature press plate of $175^{\circ} \mathrm{C}$, and at the ratio of adhesive of $6 \%$.

ANOVA is a statistical method used to determine the individual interactions of all of the control factors in the test design. In this study, analysis of variance was used to determine the percent contribution of each parameter on output $(M O E)$. However, in order to determine whether the parameters used in ANOVA analysis have a statistically significant effect on the result, an analysis called $F$-test is required. The results of ANOVA analysis of $S / N$ ratios are shown in Table 4 . This analysis was carried out at a $5 \%$ significance level and a $95 \%$ confidence level.

With $F$-distribution table for alpha $=0.05$, with numerator of degrees of freedom 2 and denominator degrees of freedom 18 (df for Error), the $F$ critical value was found to be 3.5546 . Therefore, according to the values obtained in Table 4, it was concluded that just parameters $\mathrm{B}$ and $\mathrm{D}$ have a significant effect on the result.

As shown in Table 4, the percentage contributions of the A, B, C and D factors on the $M O E$ were found to be $7.51 \%, 42.43 \%, 0.27 \%$ and $24.31 \%$, respectively. Thus, the most important factor affecting the MOE is "Time" (factor B, $42.43 \%$ ).

\subsection{Test of confirmation}

3.1. Potvrdni test

The final step in the design of experiments with the Taguchi method is to perform a validation test. The purpose of the validation test is to confirm the results and discussions in the analysis section. The confirmation test is a crucial step and is highly recommended by Taguchi to verify the experimental results as stated by Ross (1996). The results of confirmation experiments in Table 5 show the comparison of the predicted by using design of experiment and experimental values.

The predicted and calculated results have very close values with the experimental results. Therefore, the results obtained from the confirmation tests reflect successful optimization.

\section{CONCLUSIONS}

\section{ZAKLJUČAK}

In this study, four main parameters in the production of oriented strand boards including temperature, pressure, time and adhesive ratio at three different levels were investigated using Taguchi's experimental design. The purpose of the design of the experiment is to achieve the optimal setting of control parameters which would result in maximum modulus of elasticity. In addition to these analyzes, analysis of variance was used to determine the percentage contribution of each parameter on output (modulus of elasticity). Furthermore, the validity of the approach was tested. Accordingly:

- The optimum levels of the control parameter for maximizing the modulus of elasticity using $\mathrm{S} / \mathrm{N}$ rates were determined. The optimal conditions for this output are at A2B2C1D1 (i.e., Pressure $=40$ $\mathrm{kg} / \mathrm{cm}^{2}$, Time $=6 \mathrm{~min}$., Temperature $=175^{\circ} \mathrm{C}$ and adhesive ratio $=6 \%$ )

- According to the results of statistical analyses, it was found that the "time" and "adhesive ratio" were the most significant parameters for MOE value with a percentage contribution of $42.43 \%$ and $24.31 \%$, respectively.

Table 4 Result of ANOVA analysis

Tablica 4. Rezultati ANOVA analize

\begin{tabular}{|c|c|c|c|c|c|c|}
\hline Source & $\boldsymbol{D F}$ & Adj SS & Adj MS & $\boldsymbol{F}$-value & $\boldsymbol{P}$-value & Contribution, $\%$ \\
\hline A & 2 & 6172788 & 3086394 & 2.65 & 0.098 & 7.51 \\
\hline B & 2 & 34871788 & 17435894 & 14.99 & 0.000 & 42.43 \\
\hline C & 2 & 221781 & 110890 & 0.10 & 0.910 & 0.27 \\
\hline D & 2 & 19979775 & 9989887 & 8.59 & 0.002 & 24.31 \\
\hline Error & 18 & 20937379 & 1163188 & & & 25.48 \\
\hline Total & 26 & 6172788 & 3086394 & 2.65 & 0.098 & 100.00 \\
\hline
\end{tabular}

Table 5 Comparative results for confirmation tests

Tablica 5. Usporedni rezultati za potvrdne testove

\begin{tabular}{|c|c|c|c|c|c|c|c|}
\hline & \multicolumn{4}{|c|}{$\begin{array}{c}\text { Optimal parameter condition } \\
\text { Optimalni uvjeti parametara }\end{array}$} & \multicolumn{2}{|c|}{$\begin{array}{c}\text { The value of } M O E \\
\text { Vrijednost } M O E\end{array}$} & \multirow{2}{*}{$\begin{array}{c}\text { Error } \\
\text { Pogrě̌ka } \\
\%\end{array}$} \\
\hline & $\begin{array}{c}\text { Pressure } \\
\text { Tlak, } \mathrm{kg} / \mathrm{cm}^{2}\end{array}$ & \begin{tabular}{|c|} 
Time \\
Vrijeme, $\min$
\end{tabular} & $\begin{array}{l}\text { Temperature } \\
\text { Temperatura, }{ }^{\circ} \mathrm{C}\end{array}$ & \begin{tabular}{|c|} 
Adhesive ratio \\
Omjer adhezije, \%
\end{tabular} & \begin{tabular}{|c|} 
Predicted \\
Predvidena
\end{tabular} & $\begin{array}{c}\text { Experimental } \\
\text { Eksperimentalna }\end{array}$ & \\
\hline Optimum & 40 & 6 & 175 & 6 & 7468 & 7437 & 0.41 \\
\hline Random 1 & 50 & 9 & 185 & 6 & 5593 & 5641 & 0.85 \\
\hline Random 2 & 30 & 6 & 195 & 12 & 5061 & 4932 & 2.58 \\
\hline
\end{tabular}


- According to the confirmation test, the results and discussions in the analysis section were verified.

Researchers studying this subject can optimize other mechanical properties (withdraw screw or nail, shock strength, internal bond, etc.) and physical properties (water absorption, thickness swelling, surface roughness, etc.) of OSBs by Taguchi or other experimental design methods according to the type of OSB panels.

\section{Acknowledgements - Zahvala}

The authors would like to express sincere gratitude to the anonymous referees and the editor for their valuable comments and suggestions that significantly improved the final version of this paper.

\section{REFERENCES}

\section{LITERATURA}

1. Agrawal, K. K.; Bhardwaj, M.; Misra, R.; Agrawal, G. D.; Bansal, V., 2018: Optimization of operating parameters of earth air tunnel heat exchanger for space cooling: Taguchi method approach. Geothermal Energy, 6 (1): 10. https://doi.org/10.1186/s40517-018-0097-0.

2. Auchet, S.; Pelaingre, C.; Barlier, C.; Meausoone, P. J., 2018: Influence of cutting and tool parameters on thrust force in drilling of different formaldehyde emission rate particleboards. Pro Ligno, 14 (1): 3-12.

3. Aydin, I.; Colakoglu, G.; Colak, S.; Demirkir, C., 2006: Effects of moisture content on formaldehyde emission and mechanical properties of plywood. Building and Environment, 41 (10): 1311-1316.

https://doi.org/10.1016/j.buildenv.2005.05.011.

4. Barnes, D., 2000: An integrated model of the effect of processing parameters on the strength properties of oriented strand wood products. Forest Products Journal, 50 (11): $33-42$

5. Benetto, E.; Becker, M.; Welfring, J., 2009: Life cycle assessment of oriented strand boards (OSB): from process innovation to ecodesign. Environmental Science \& Technology, 43 (15): 6003-6009. https://doi.org/10.1021/es900707u.

6. Bisgaard, S., 1991: Teaching statistics to engineers. The American Statistician, 45 (4): 274-283.

7. Ciobanu, V. D.; Zeleniuc, O.; Dumitrascu, A.-E.; Lepadatescu, B.; Iancu, B., 2014: The influence of speed and press factor on oriented strand board performance in continuous press. BioResources, 9 (4): 6805-6816.

8. Davim, J. P.; Gaitonde, V. N.; Karnik, S. R., 2008: An investigative study of delamination in drilling of medium density fibreboard (MDF) using response surface models. The International Journal of Advanced Manufacturing Technology, 37 (1): 49-57. https://doi.org/10.1007/s00170-007-0937-8.

9. Davis, R.; John, P., 2018: Application of Taguchi-based design of experiments for industrial chemical processes. Statistical Approaches With Emphasis on Design of Experiments Applied to Chemical Processes, 137.

10. Dumitrascu, A.-E.; Lunguleasa, A.; Salca, E.-A.; Ciobanu, V. D., 2020: Evaluation of selected properties of oriented strand boards made from fast growing wood species. BioResources, 15 (1): 199-210.

11. Fatrawana, A.; Maulana, S.; Nawawi, D. S.; Sari, R. K.; Hidayat, W.; Park, S. H.; Febrianto, F.; Lee, S. H.; Kim, N. H., 2019: Changes in chemical components of steamtreated betung bamboo strands and their effects on the physical and mechanical properties of bamboo-oriented strand boards. European Journal of Wood and Wood Products, 77 (5): 731-739.

https://doi.org/10.1007/s00107-019-01426-7.

12. Ferro, F. S.; Silva, D. A. L.; Lahr, F. A. R.; Argenton, M.; González-García, S., 2018: Environmental aspects of oriented strand boards production. A Brazilian case study. Journal of Cleaner Production, 183: 710-719. https://doi.org/10.1016/j.jclepro.2018.02.174.

13. Fisher, R. A., 1992: Statistical methods for research workers. In: Breakthroughs in statistics. Springer, pp. 6670 .

14. Jin, J.; Chen, S.; Wellwood, R., 2016: Oriented strand board: Opportunities and potential products in China. BioResources, 11 (4): 10585-10603.

15. Kasal, A., 2008: Estimation equations for moment resistances of L-type screw corner joints in case goods furniture. Forest Products Journal, 58 (9): 21-27.

16. Rebollar, M.; Pérez, R.; Vidal, R., 2007: Comparison between oriented strand boards and other wood-based panels for the manufacture of furniture. Materials \& Design, 28 (3): 882-888. https://doi.org/10.1016/j.matdes.2005.10.012.

17. Ross, P. J., 1996: Taguchi techniques for quality engineering: loss function, orthogonal experiments, parameter and tolerance design, $2^{\text {nd }}$ ed. McGraw Hill.

18. Semple, K.; Zhang, P.; Smith, G., 2015: Hybrid oriented strand boards made from Moso bamboo (Phyllostachys pubescens Mazel) and Aspen (Populus tremuloides Michx.): species-separated three-layer boards. European Journal of Wood and Wood Products, 73 (4): 527-536. https://doi.org/10.1007/s00107-015-0914-0.

19. Smardzewski, J., 2019: Experimental and numerical analysis of wooden sandwich panels with an auxetic core and oval cells. Materials \& Design, 183: 108159. https:// doi.org/10.1016/j.matdes.2019.108159.

20. Spelter, H. N.; McKeever, D. B.; Durbak, I., 1997: Review of wood-based panel sector in United States and Canada (General technical report FPL; GTR-99).

21. Sumardi, I.; Ono, K.; Suzuki, S., 2007: Effect of board density and layer structure on the mechanical properties of bamboo oriented strandboard. Journal of Wood Science, 53 (6): 510-515.

https://doi.org/10.1007/s10086-007-0893-9.

22. Velosa, J.; Rana, S.; Santos, T.; Fangueiro, R.; Ramos, L., 2013: Application of Taguchi method in optimizing fabrication of composite panels for interior dividing walls. Polymers and Polymer Composites, 21 (6): 387-394. https://doi.org/10.1177/096739111302100607.

23. ***EN 310, 1996: Wood-based panels: determination of modulus of elasticity in bending and of bending strength. Brussels.

24. ***EN 300, 2006: Oriented strand boards (OSB). Definitions, classification and specifications.

\section{Corresponding address:}

\section{FATIH YAPICI}

Ondokuz Mayıs University

Faculty of Engineering

Department of Industrial Engineering

Samsun, TURKEY

e-mail: fatih.yapici@omu.edu.tr 